\title{
Nutrient removal and microbial settlement in a full-scale subsurface wastewater infiltration system: Impact of varying hydraulic and organic loads and temperature
}

\author{
Yafei Sun ${ }^{1 \#, ~ L i n l i n ~ F a n " 1 \#, ~ D e l i ~ T o n g ~}{ }^{1 \#}$, Zhiqi Li ${ }^{1 \#}$, Fanping Zheng ${ }^{1}$, Wanyuan Hou' ${ }^{1}$ and Jing Pan ${ }^{1 *}$ \\ ${ }^{\prime}$ College of Life Science, Shenyang Normal University, Shenyang, China
}

\begin{abstract}
A series of experiments was conducted through a full-scale subsurface wastewater infiltration system (SWIS) to investigate the impact of hydraulic loading rate (HLR), organic loading rate (OLR) and underground temperature on nutrient removal and microbial settlement. Taking the hydraulic and treatment performance into consideration, HLR of $0.10 \mathrm{~m}^{3} /\left(\mathrm{m}^{2} \cdot \mathrm{d}\right)$ was recommended with average $\mathrm{NH}_{3}-\mathrm{N}, \mathrm{TN}, \mathrm{COD}$ and TP removal rates of $82.6 \%, 81.5 \%, 80.9 \%$ and $90.9 \%$, respectively. Considering treatment performance, OLR of $10.4 \mathrm{~g} \mathrm{BOD} /\left(\mathrm{m}^{2} \cdot \mathrm{d}\right)$ was recommended with average $\mathrm{NH}_{3}-\mathrm{N}, \mathrm{TN}, \mathrm{COD}$ and TP removal rates of $88.1 \%, 84.8 \%, 86.3 \%$ and $91.3 \%$, respectively. The number of nitrifying bacteria in each layer in the matrix decreased with increasing HLR, and the number of denitrifying bacteria increased with increasing HLR, at 0.8 and 1.0 $\mathrm{m}$ depths. When OLR increased, the number of bacteria and denitrifying bacteria at 0.8 and $1.0 \mathrm{~m}$ depths increased, and the number of nitrifying bacteria decreased. Average $\mathrm{NH}_{3}-\mathrm{N}, \mathrm{TN}$ and $\mathrm{COD}$ removal rates increased with underground temperature increasing. The number of bacteria, nitrifying bacteria at 0.4 and $0.6 \mathrm{~m}$ depths and denitrifying bacteria at 0.8 and $1.0 \mathrm{~m}$ depths, increased with underground temperature increasing.
\end{abstract}

Keywords: decentralized wastewater; nitrifying bacteria; denitrifying bacteria; soil treatment system

\section{INTRODUCTION}

Wastewater treatment is becoming ever more critical due to diminishing water resources, increasing wastewater disposal costs, and stricter discharge regulations that have lowered permissible contaminant levels in waste streams. It has been estimated that $95 \% \mathrm{f}$ decentralized wastewater around the world is discharged into the environment without any treatment (Li et al., 2011a). The subsurface wastewater infiltration system (SWIS) has proven to be a good alternative for decentralized wastewater treatment, with consideration to pollutant removal, and construction and operating costs (Zhang et al., 2005; Li et al., 2011a). Former studies have revealed that hydraulic loading rate (HLR) or organic loading rate (OLR) is one of the major operational factors affecting the performance of a soil treatment system (Kadam et al., 2009; Li et al., 2011b; Fei et al., 2016). Temperature is one of the environmental variables which affects biological activity and seasonal removal performances of SWISs (Li et al., 2011b; 2012). Zou et al. (2009) explored the effect of amended soil and hydraulic load on biological nitrogen removal in lab-scale SWIS. Yin and Shen (1995) reported that the proliferation ability and activity of bacteria involved in nitrogen removal were suppressed at low temperature. To date, very few studies have been carried out on the effects of HLR, OLR and underground temperature on pollutant removal performance of a full-scale SWIS treating domestic wastewater. The main purpose of this study was to: (i) investigate the effects of HLR, OLR and underground temperature on nutrient removal and

To whom all correspondence should be addressed.

+8624 86593328; fax: +862486592584;

e-mail: crystalpan78@126.com

Received 13 March 2017; accepted in revised form 15 June 2018

\#These authors contributed equally to this study and share first authorship. microbial settlement in a full-scale SWIS; (ii) to provide a reference point for full-scale SWIS operation.

\section{MATERIALS AND METHODS}

\section{System description and operation}

As shown in Fig. 1, the SWIS covered $576 \mathrm{~m}^{2}$ and was divided into 2 equal units with effective depth of $1.2 \mathrm{~m}$, to treat wastewater from a dormitory building (serving 1 000 students), a public bathhouse (serving 2000 persons) and a public canteen (serving more than 2000 persons) in Shenyang Normal University campus. Each unit could be fed with wastewater separately. Seven distributing pipes 0.2 $\mathrm{m}$ in diameter were constructed in each unit. The domestic wastewater after pre-sedimentation was pumped into the distributing pipes, which were $0.5 \mathrm{~m}$ below the SWIS. The interval between distributing pipes was $2.0 \mathrm{~m}$. In order to monitor the microbial community, sampling points were installed vertically between two distributing pipes at 0.4 , $0.6,0.8$ and $1.0 \mathrm{~m}$ depths from the top of the two units. The treated wastewater was collected in the collecting pipe 1.2 $\mathrm{m}$ below. The matrix of the SWIS was $70 \%$ local brown soil and $30 \%$ coal slag (by weight), evenly mixed. Brown soil is the major soil type in warm and humid climatic areas. Since brown soil has low permeability, which makes it unsuitable as the sole filtration medium of the SWIS, coal slag is used as the main modifying material (Li et al., 2011b). The coal slag was purchased from a local market in Shenyang, and was 4-8 $\mathrm{mm}$ in diameter. The surface of the SWIS was planted with grass. The effluent of the SWIS, after disinfection, was used for irrigating the landscape in summer and for cleaning and flushing toilets on campus in winter. The SWIS functioned in the purification and reuse of wastewater. 

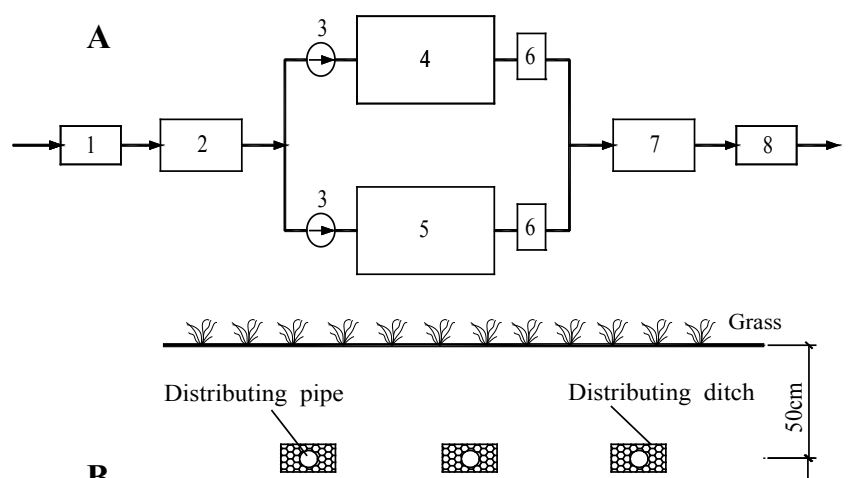

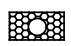

Distributing ditch

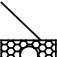

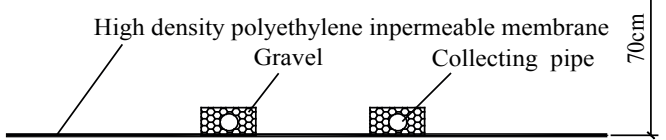

Figure 1

Schematic diagram of the SWIS: (A) top view (B) profile (1) settling tank (2) regulating tank (3) flow pump (4-5) two units of SWIS (6) collecting well (7) disinfecting tank (8) collecting tank

HLR and OLR were varied separately for the two units from June to August 2012, with underground temperature of $23 \pm 3.3^{\circ} \mathrm{C}$. Following the above experiments, the SWIS was operated under the optimal HLR with underground temperatures of $12 \pm 1.3^{\circ} \mathrm{C}, 16 \pm 1.6^{\circ} \mathrm{C}, 20 \pm 1.8^{\circ} \mathrm{C}$ and $25 \pm 1.5^{\circ} \mathrm{C}$, from January to August 2013. Underground temperature was measured through in situ temperature sensors which had been buried at $0.5 \mathrm{~m}$ depth in the two units.

\section{Wastewater characteristics}

Wastewater was pre-treated in a septic tank prior to being discharged into each unit continuously. The range of wastewater parameters after pre-treatment were $\mathrm{pH}$ 6.7-7.5, COD 185.3-262.4 mg/L, TN 33.9-46.7 mg/L, TP 3.2-8.3 mg/L, $\mathrm{NH}_{3}-\mathrm{N} 30.3-44.6 \mathrm{mg} / \mathrm{L}$.

\section{Sampling and analytical methods}

The influent and effluent samples were collected every 3 days. COD, $\mathrm{TN}, \mathrm{NH}_{3}-\mathrm{N}$ and $\mathrm{TP}$ of the water samples were analysed according to standard methods (APHA, 2003). Matrix samples were collected from sampling ports every 3 days for a microbial count using plate counts. The nitrifying and denitrifying bacteria were counted using the most probable number (MPN) calculation (Molle et al., 2006). All samples were taken to the laboratory and analysed immediately. The analyses were repeated 3 times and means reported.

\section{RESULTS AND DISCUSSION}

\section{Effects of HLR on nutrient removal and microbial settlement}

HLR was an important factor influencing the removal performance of a soil treatment system. A relatively high HLR could not maintain stable operation over the long term; relatively low HLR would demand too much soil. The organic matter degradation process in a SWIS is as follows: after being fed, soil firstly adsorbs organic matter, and then the adsorbed organic matter is gradually converted into low-molecularweight matter by microorganisms through fermentation and/or respiration, and mineralized as a source of energy or assimilated into biomass (Li et al., 2011b). Therefore, COD removal rate always decreased gradually because of adsorption saturation (Li et al., 2012). During the first experiment, HLRs of $0.04,0.07,0.10$ and $0.13 \mathrm{~m}^{3} /\left(\mathrm{m}^{2} \cdot \mathrm{d}\right)$ were presented in order to explore the effects of HLR on pollutant removal. As seen from Fig. 2, average COD and TP removal rates dropped dramatically from $89.9 \%$ to $77.1 \%$ and from $96.3 \%$ to $90.2 \%$, respectively, when HLR increased from $0.04 \mathrm{~m}^{3} /\left(\mathrm{m}^{2} \cdot \mathrm{d}\right)$ to $0.13 \mathrm{~m}^{3} /\left(\mathrm{m}^{2} \cdot \mathrm{d}\right)$. The reason for this decrease was due to there being fewer adsorption sites. These observations indicated that hydraulic loadings affected COD removal in the following ways: Firstly, increasing hydraulic loadings led to scour of more media surfaces. Secondly, increasing hydraulic loadings meant shortening hydraulic retention time, so organic matter was not fully degraded. Phosphorus removal mechanisms include physical sedimentation, chemical adsorption and precipitation and biological processes in the soil (Brooks et al., 2000). Brooks et al. (2000) also revealed a positive correlation between phosphorus removal rate and the SWIS surface area. Herein, average TP removal rate decreased with increasing HLR.

In a SWIS, $\mathrm{NH}_{3}-\mathrm{N}$ is absorbed onto the surface of soil particles with negative charges, and then transformed into $\mathrm{NO}_{3}-\mathrm{N}$ via microbial nitrification. Nitrification occurred only when oxygen was present at a high enough concentration to support the growth of strictly aerobic nitrifying bacteria (Li et al., 2011b). In the current study, HLR had an obviously negative influence on $\mathrm{NH}_{3}-\mathrm{N}$ removal. Average removal rate of $\mathrm{NH}_{3}-\mathrm{N}$ declined from $89.7 \%$ under HLR of $0.04 \mathrm{~m}^{3} /\left(\mathrm{m}^{2} \cdot \mathrm{d}\right)$ to $72.3 \%$ under $0.13 \mathrm{~m}^{3} /\left(\mathrm{m}^{2} \cdot \mathrm{d}\right.$ ) (Fig. 3). When HLR increased to $0.13 \mathrm{~m}^{3} /$ $\left(\mathrm{m}^{2} \cdot \mathrm{d}\right)$, soil clogging occurred due to overfeeding and resulted in a marked elevation of $\mathrm{NH}_{3}-\mathrm{N}$ concentration in the effluent. These observations confirmed that clogging prevented oxygen from diffusing into the soil matrix and lower oxygen caused the insufficient transformation of $\mathrm{NH}_{3}-\mathrm{N}$ to $\mathrm{NO}_{2}-\mathrm{N}$ or $\mathrm{NO}_{3}-\mathrm{N}$. Correspondingly, average $\mathrm{TN}$ removal rate decreased from $86.1 \%$ to $62.9 \%$ with HLR increasing from $0.04 \mathrm{~m}^{3} /\left(\mathrm{m}^{2} \cdot \mathrm{d}\right)$ to $0.13 \mathrm{~m}^{3} /\left(\mathrm{m}^{2} \cdot \mathrm{d}\right)$. In a SWIS, nitrogen is removed by volatilization, adsorption, plant uptake and nitrification-denitrification (Li et al., 2011a). In this study, $\mathrm{pH}$ in the SWIS matrix was found to be 7.3. Nitrogen loss through volatilization was negligible because volatilization was generally insignificant at $\mathrm{pH}$ below 9.3 (Li et al., 2011a; 2012). $\mathrm{NH}_{3}-\mathrm{N}$ could be adsorbed on the matrix; however, such removal was not considered to be a long-term sink because the adsorbed $\mathrm{NH}_{3}-\mathrm{N}$ was released easily when water chemistry conditions changed (Kadam et al., 2009). Simultaneous nitrification and denitrification are the main means of nitrogen removal in the SWIS (Wang et al., 2010; Zhang et al., 2005). The process of nitrification is $\mathrm{NH}_{4}^{+}{ }_{-}$ $\mathrm{N} \rightarrow \mathrm{NO}_{2}-\mathrm{N} \rightarrow \mathrm{NO}_{3}^{-}-\mathrm{N}$ and the route of denitrification is $\mathrm{NO}_{3}^{-}-$ $\mathrm{N} \rightarrow \mathrm{NO}_{2}^{-}-\mathrm{N} \rightarrow \mathrm{NO} \rightarrow \mathrm{N}_{2} \mathrm{O} \rightarrow \mathrm{N}_{2}$ (Li et al., 2011b). It has been reported that to complete the nitrification process successfully, dissolved oxygen concentrations above $1.5 \mathrm{mg} / \mathrm{L}$ are essential (Molle et al., 2006). Herein, when HLR was $0.13 \mathrm{~m}^{3} /\left(\mathrm{m}^{2} \cdot \mathrm{d}\right), 0.65 \pm 0.2$ $\mathrm{mg} / \mathrm{L}$ DO concentration in the effluent was achieved, $1.76 \pm 0.1$ $\mathrm{mg} / \mathrm{L}$ lower than the one under HLR of $0.10 \mathrm{~m}^{3} /\left(\mathrm{m}^{2} \cdot \mathrm{d}\right) . \mathrm{NH}_{3}-\mathrm{N}$ comprised $90 \%$ of TN in the study wastewater. TN removal rate dropped dramatically under HLR of $0.13 \mathrm{~m}^{3} /\left(\mathrm{m}^{2} \cdot \mathrm{d}\right)$ because of limited nitrification. Before soil clogging occurred, even when HLR was as high as $0.10 \mathrm{~m}^{3} /\left(\mathrm{m}^{2} \cdot \mathrm{d}\right)$, average removal rates of $\mathrm{NH}_{3}-\mathrm{N}$ and TN were $82.6 \%$ and $81.5 \%$, respectively. Average effluent concentration for COD was $51.9 \pm 3.6 \mathrm{mg} / \mathrm{L}$ under HLR of $0.13 \mathrm{~m}^{3} /\left(\mathrm{m}^{2} \cdot \mathrm{d}\right)$, which was higher than the Chinese Criterion for Water Quality Standard for Urban Miscellaneous Water 
Consumption (CJ 25.1-89 1). According to the results, to achieve high effluent quality and hydraulic efficiency in a SWIS, HLR of $0.10 \mathrm{~m}^{3} /\left(\mathrm{m}^{2} \cdot \mathrm{d}\right)$ was optimal (Figs 2 and 3 ).
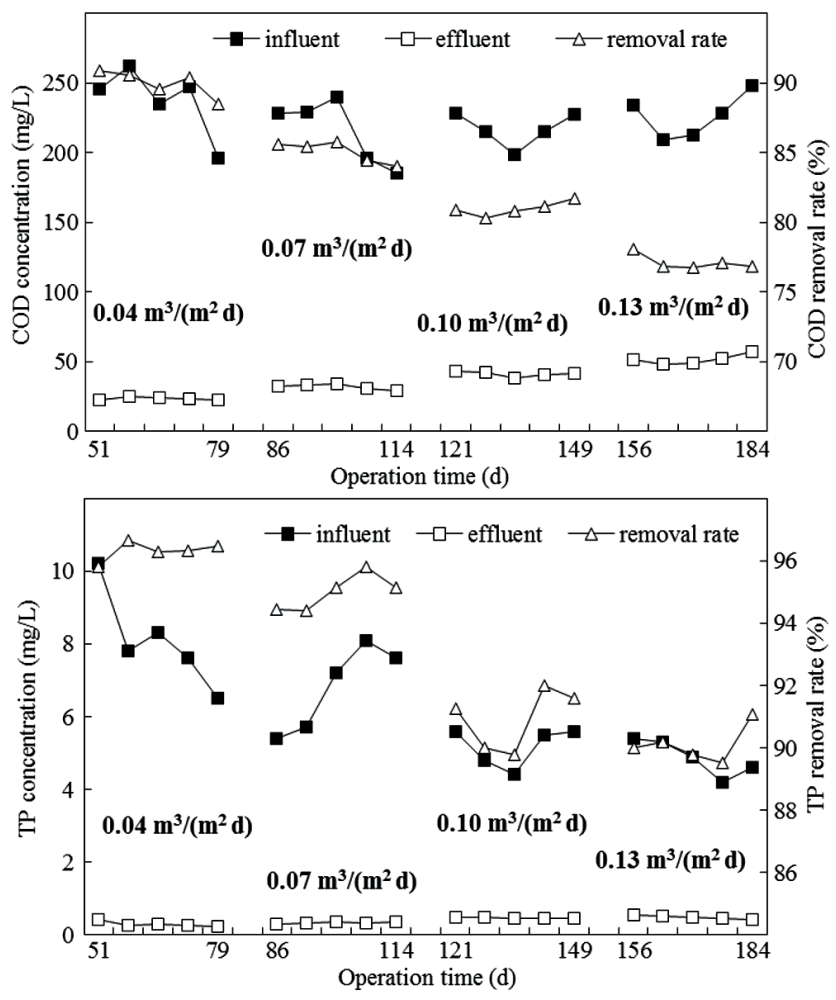

Figure 2

Effect of hydraulic loading rate on COD and TP removal
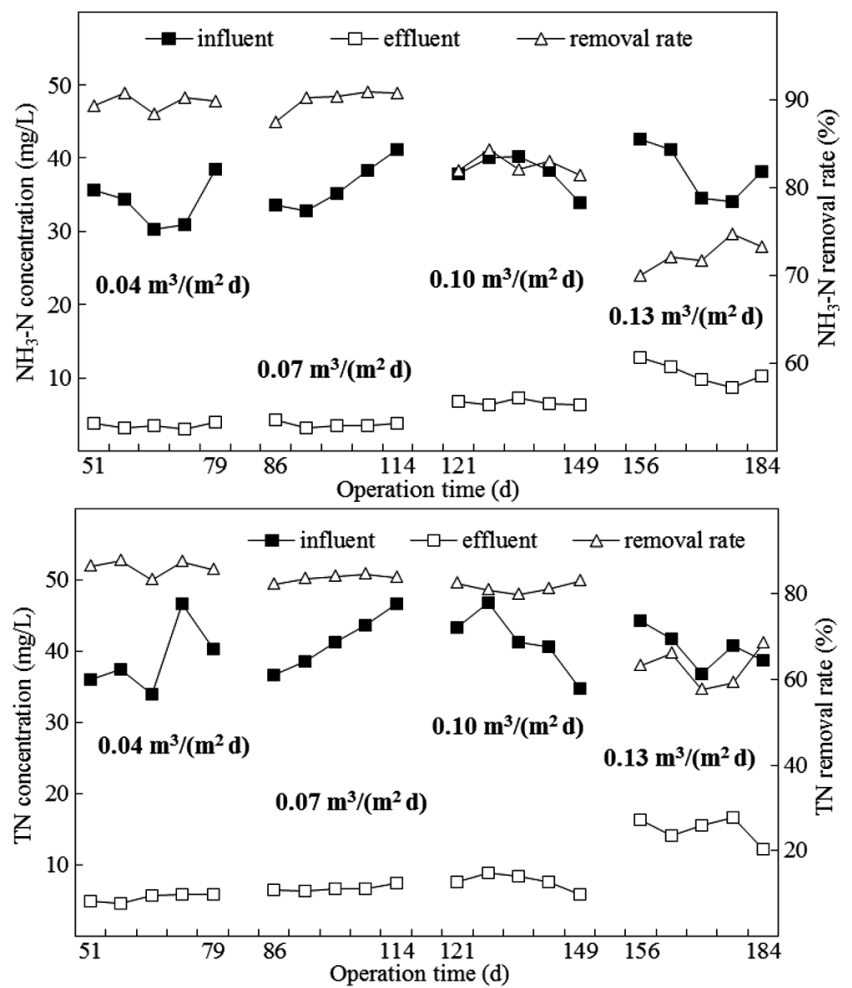

Figure 3

Effect of hydraulic loading rate on $\mathrm{NH}_{3}-\mathrm{N}$ and $\mathrm{TN}$ removal
From Fig. 4, the number of bacteria in each layer in the matrix increased 10 times, when HLR increased from $0.04 \mathrm{~m}^{3} /$ $\left(\mathrm{m}^{2} \cdot \mathrm{d}\right)$ to $0.10 \mathrm{~m}^{3} /\left(\mathrm{m}^{2} \cdot \mathrm{d}\right)$. Under low HLR, bacteria couldn't obtain enough nutrients, which was disadvantageous to the growth and reproduction of bacteria. The number of bacteria in each layer in the matrix decreased 10 times when HLR increased from $0.10 \mathrm{~m}^{3} /\left(\mathrm{m}^{2} \cdot \mathrm{d}\right)$ to $0.13 \mathrm{~m}^{3} /\left(\mathrm{m}^{2} \cdot \mathrm{d}\right)$. Under high HLR, retention time of wastewater was short and the matrix was partially flooded, which did not favour the growth and reproduction of bacteria (Molle et al., 2006). Organic pollutants in the influent were mainly oxidized in the upper matrix, with sufficient oxygen in the infiltration systems, by bacteria, fungus, actinomyces and protozoans, etc. (Pan et al., 2013). In this study, average COD removal rate was consistent with the change in bacteria. The number of nitrifying bacteria of each layer in the matrix decreased with the increase in HLR. When HLR increased by $0.03 \mathrm{~m}^{3} /\left(\mathrm{m}^{2} \cdot \mathrm{d}\right)$, the number of nitrifying bacteria decreased 10 times. These observations confirmed that HLR could affect the number of nitrifying bacteria in the following ways. Firstly, increasing hydraulic loadings meant shortening of hydraulic retention time, which caused the matrix oxidation reduction potential to decrease, which
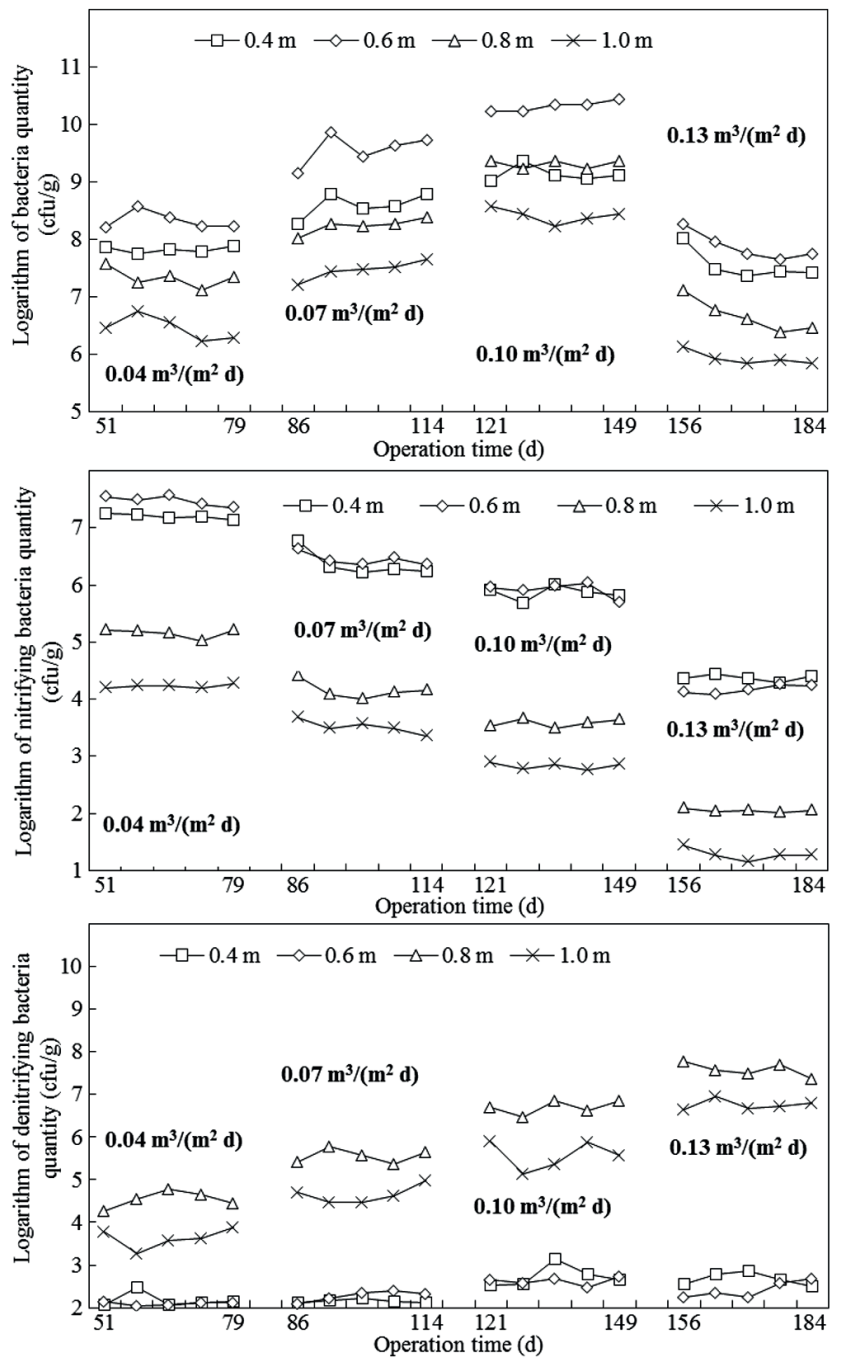

Figure 4

Effect of hydraulic loading rate on microbial community 
hindered the growth and reproduction of nitrifying bacteria ( $\mathrm{Li}$ et al., 2011b). Secondly, high HLR accelerated matrix surface biological membrane replacement, which was not conducive to the growth and reproduction of nitrifiying bacteria, because of the long generation period of nitrifying bacteria (Pan et al., 2013). When HLR increased by $0.03 \mathrm{~m}^{3} /\left(\mathrm{m}^{2} \cdot \mathrm{d}\right)$, the number of denitrifying bacteria increased 10 times at 0.8 and $1.0 \mathrm{~m}$ depth.

\section{Effects of OLR on nutrient removal and microbial settlement}

During this experiment, OLRs of 2.5, 6.8, 10.4 and 14.2 $\mathrm{g} \mathrm{BOD} /\left(\mathrm{m}^{2} \cdot \mathrm{d}\right)$ were presented. As seen from Figs 5 and 6 , average $\mathrm{COD}, \mathrm{NH}_{3}-\mathrm{N}$ and $\mathrm{TN}$ removal rates decreased with increasing OLR, which was in accordance with other studies (Li et al., 2011b). When OLR increased from $2.5 \mathrm{~g} \mathrm{BOD} /\left(\mathrm{m}^{2} \cdot \mathrm{d}\right)$ to $14.2 \mathrm{~g} \mathrm{BOD} /\left(\mathrm{m}^{2} \cdot \mathrm{d}\right)$, average removal rates dropped from $91.2 \%$ to $75.6 \%$ for COD, from $93.1 \%$ to $70.5 \%$ for $\mathrm{NH}_{3}-\mathrm{N}$ and from $77.9 \%$ to $65.6 \%$ for TN. The oxygen availability was considered to be one of the main rate-limiting factors for organics degradation and nitrification. A previous study by Zhang et al. (2005) showed that oxygen supply from air diffused to the matrix was limited. $\mathrm{COD}$ and $\mathrm{NH}_{3}-\mathrm{N}$ removal rates decreased with increasing OLR. Excellent TP removal performance was achieved under the experimental OLRs. More than $90 \%$ TP was removed. OLR had no significant effects on phosphorus removal as the physical-chemical processes were completed in a very short time period.

Average $\mathrm{COD}, \mathrm{NH}_{3}-\mathrm{N}$, and $\mathrm{TN}$ removal rates were relatively stable and high with OLR of $2.5,6.8,10.4 \mathrm{~g} \mathrm{BOD} /\left(\mathrm{m}^{2} \cdot \mathrm{d}\right)$. It could be inferred that under low OLR, the ecological structure of the microbial system was able to maintain a dynamic balance and accordingly resulted in high pollutant removal rates. Many studies have suggested that OLR is between $1.5 \mathrm{~g} \mathrm{BOD} /\left(\mathrm{m}^{2} \cdot \mathrm{d}\right)$ and $6.0 \mathrm{~g} \mathrm{BOD} /\left(\mathrm{m}^{2} \cdot \mathrm{d}\right)$ in a SWIS (Rauch and Drewes, 2006). However, the organic loading resistance of the SWIS reported on herein was relatively greater, due to the usage of coal slag. The coal slag, a type of inorganic waste produced in coal combustion, was composed of $\mathrm{SiO}_{2} 43.5 \mathrm{mg} / \mathrm{kg}, \mathrm{Al}_{2} \mathrm{O}_{3} 23.2 \mathrm{mg} / \mathrm{kg}, \mathrm{Fe}_{2} \mathrm{O}_{3}$ $11.6 \mathrm{mg} / \mathrm{kg}$, CaO $5.8 \mathrm{mg} / \mathrm{kg}$, and $\mathrm{MgO} 1.9 \mathrm{mg} / \mathrm{kg}$. At the same time, it had a large surface area, as high as $5.12 \mathrm{~m}^{2} / \mathrm{g}$. These features were useful in adsorption and immobility of $\mathrm{NH}_{3}-\mathrm{N}, \mathrm{TP}$ and organic matter. The effluent concentration for COD was 53.3 $\pm 2.9 \mathrm{mg} / \mathrm{L}$ under HLR of $14.2 \mathrm{~g} \mathrm{BOD} /\left(\mathrm{m}^{2} \cdot \mathrm{d}\right)$, which was higher than Chinese criterion for Water Quality Standard for Urban Miscellaneous Water Consumption (CJ 25.1-89 1). The above experimental results show that an OLR of $10.4 \mathrm{~g} \mathrm{BOD} /\left(\mathrm{m}^{2} \cdot \mathrm{d}\right)$ was recommended to achieve satisfactory effluent quality.

The number of bacteria in each layer in the matrix increased with an increase in OLR (Fig. 7). When OLR increased by about $4 \mathrm{~g} \mathrm{BOD} /\left(\mathrm{m}^{2} \cdot \mathrm{d}\right)$, the number of bacteria increased 10 times. With OLR increasing, bacteria could obtain enough carbon sources, which boosted their growth and reproduction. However, the number of nitrifying bacteria in each layer decreased 10 times and the number of denitrifying bacteria at 0.8 and $1.0 \mathrm{~m}$ depths increased 10 times when OLR increased by about $4 \mathrm{gBOD} /$ $\left(\mathrm{m}^{2} \cdot \mathrm{d}\right)$. These results were a consequence of competition between heterotrophic bacteria and autotrophic bacteria. The increase in OLR which resulted in a higher organic loading shifted in favour of heterotrophic bacteria relative to the contribution of autotrophic bacteria (Rauch and Drewes, 2006). In the case of substrate enrichment, heterotrophic bacteria competed with autotrophic bacteria for substrates and space, which inhibited nitrification and resulted in a rapid decrease in $\mathrm{COD}$ and $\mathrm{NH}_{3}-\mathrm{N}$ removal rates (Zou et al., 2009).

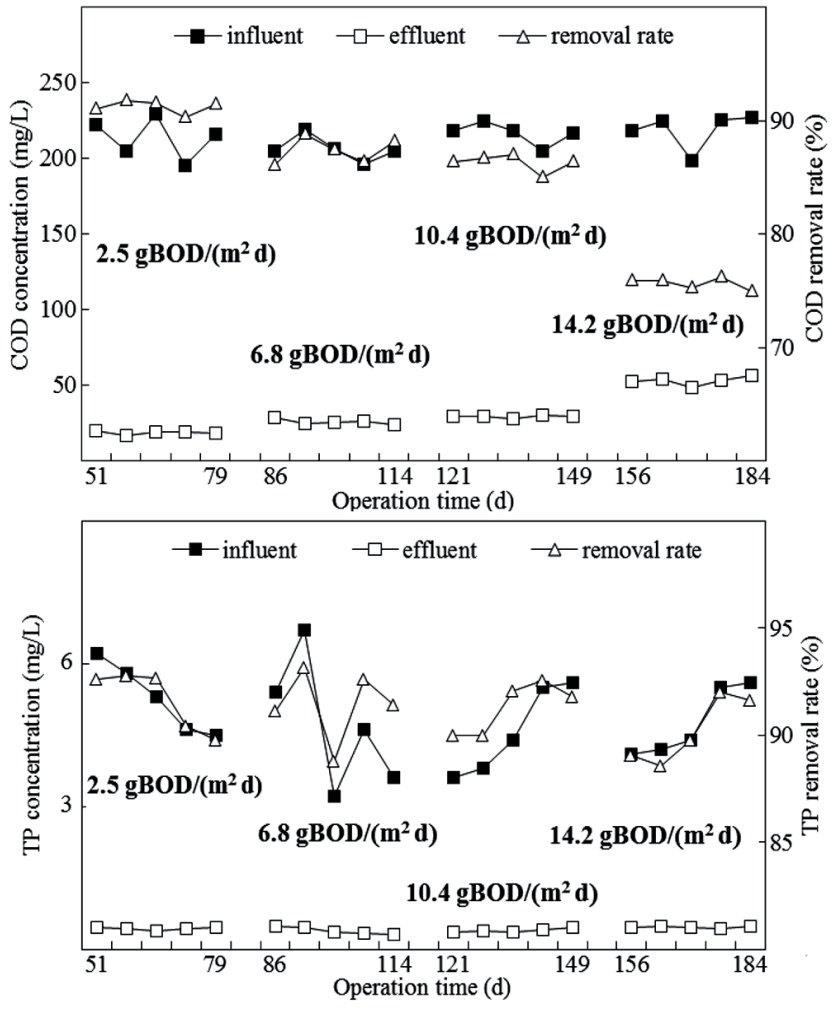

Figure 5

Effect of pollutant loading rate on COD and TP removal
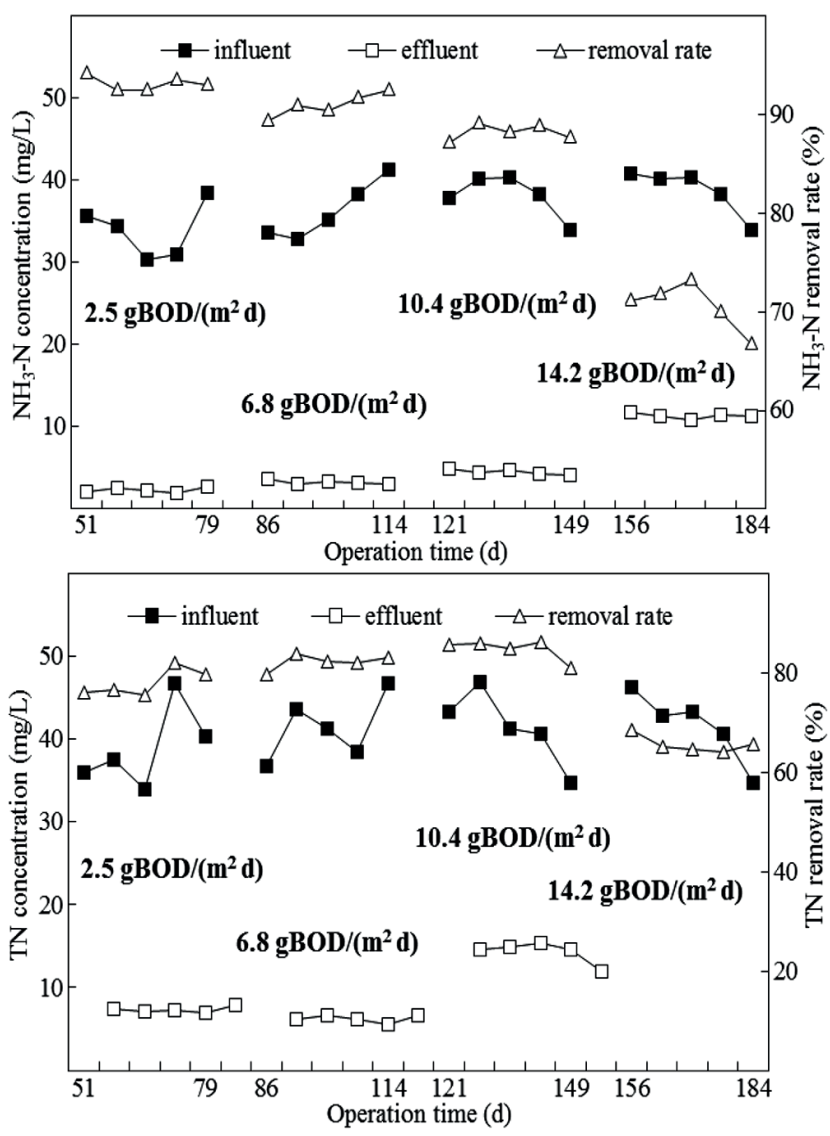

Figure 6

Effect of pollutant loading rate on $\mathrm{NH}_{3}-\mathrm{N}$ and $\mathrm{TN}$ removal 

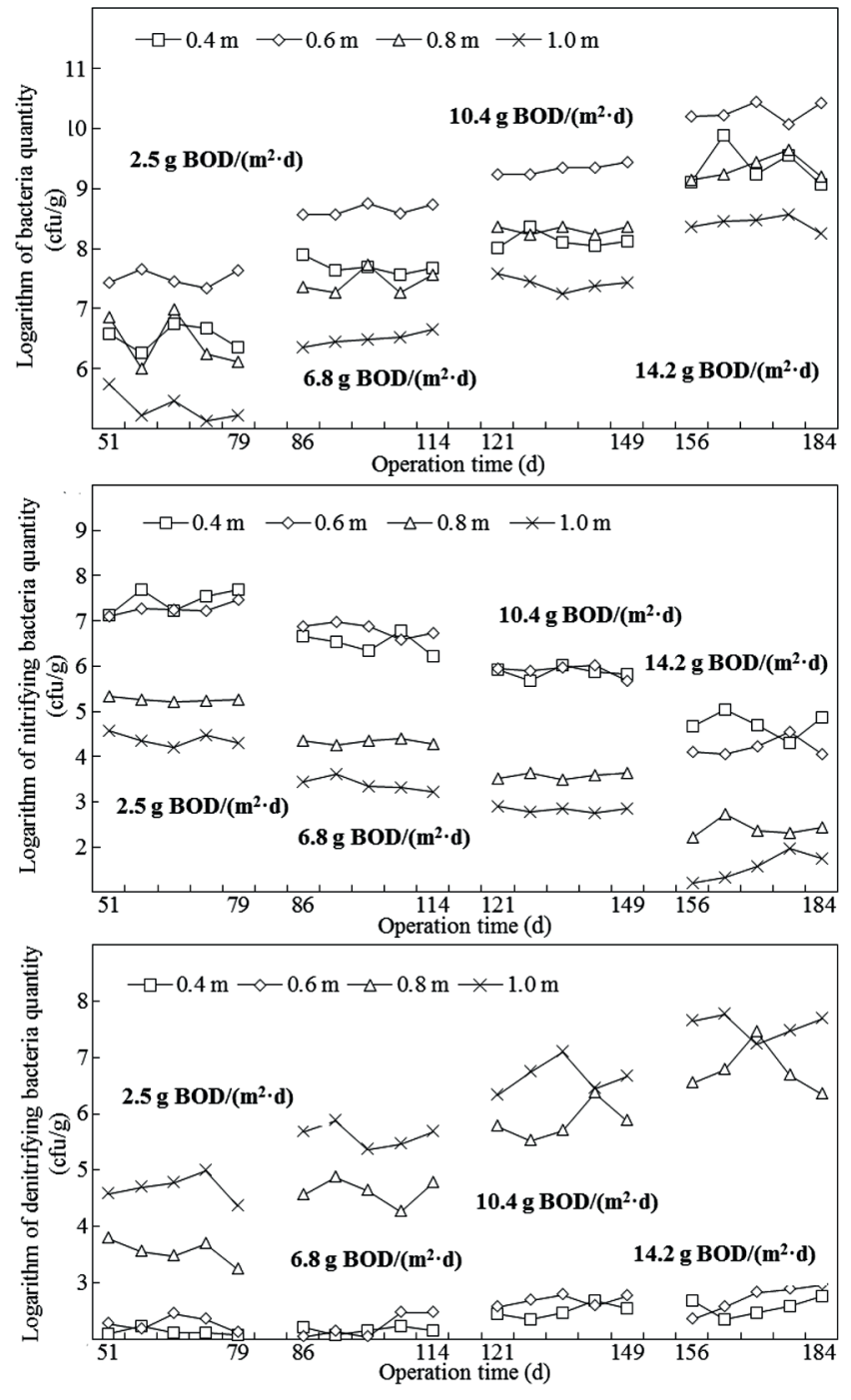

Figure 7

Effect of pollutant loading rate on microbial community

\section{Effect of temperature on nutrient removal and microbial settlement}

From January to August 2013, the SWIS was operated for 8 months with HLR of $0.10 \mathrm{~m}^{3} /\left(\mathrm{m}^{2} \cdot \mathrm{d}\right)$. During the experimental period, the lowest temperature was found to occur in January with an average outdoor temperature of $-19^{\circ} \mathrm{C}$ and the highest temperatures recorded in July and August with average outdoor temperatures of $27^{\circ} \mathrm{C}$. Pollutant removal performance is shown in Fig. 8.

Average COD removal rate was the highest at an underground temperature of $25 \pm 1.5^{\circ} \mathrm{C}(93.7 \%, 7.2-13.4 \%$ higher than for other underground temperatures). COD removal rate increased with increasing underground temperature. The results indicate that the microorganisms degrading the organic matter were temperature sensitive, with higher temperatures increasing their activity. Average TP removal rate was more than $91 \%$ in the study and was not influenced by underground temperature. Phosphorus removal in a SWIS is based on sedimentation, adsorption and biological processes (Sato et al., 2005). A previous study revealed that long-term phosphorus removal was likely due to
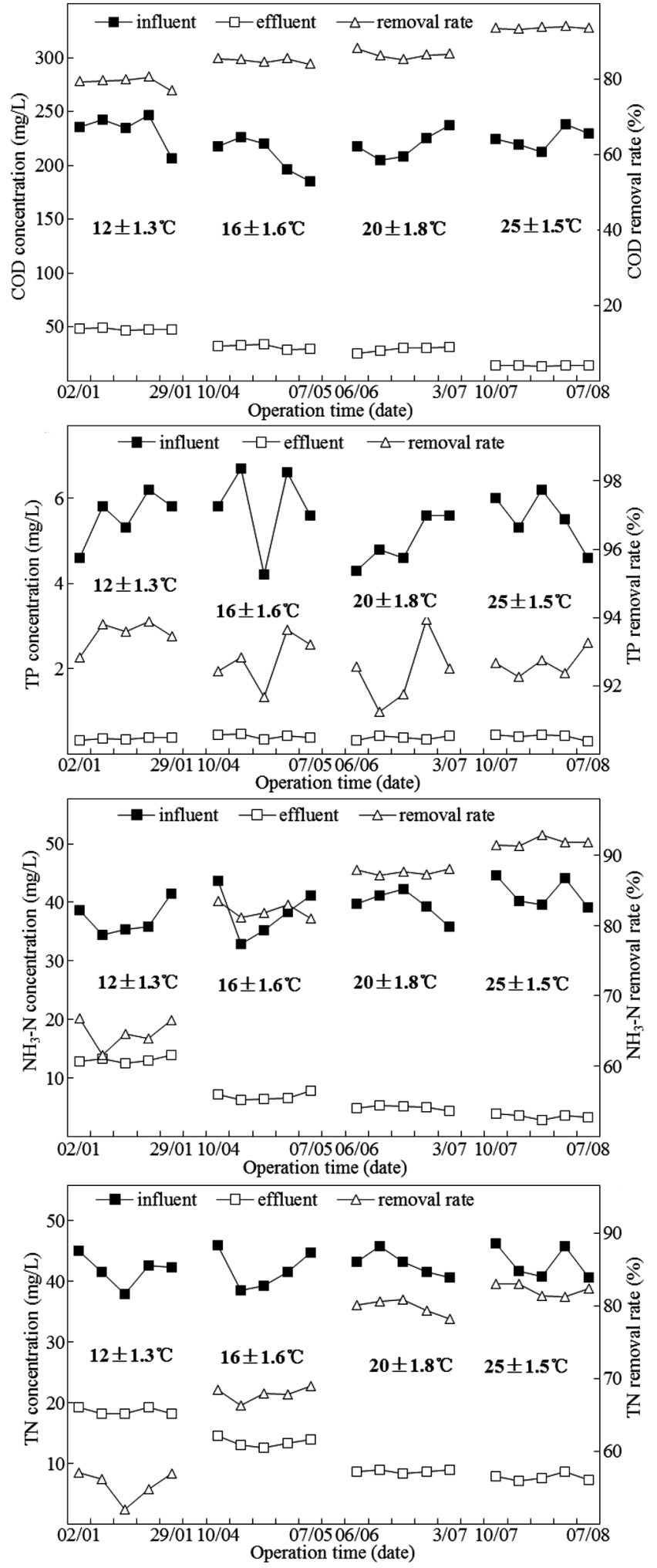

Figure 8

Effect of underground temperature on pollutant removal

uptake by the substrate and aluminium/iron compounds (Li et al., 2011a). TP removal by the SWIS was relatively high during the study because of the use of coal slag. Coal slag was the main component of the matrix and comprised of a number of aluminium/iron compounds. 
The highest average $\mathrm{NH}_{3}-\mathrm{N}$ and $\mathrm{TN}$ removal rates were $91.8 \%$ and $82.2 \%$, respectively, at an underground temperature of $25 \pm 1.5^{\circ} \mathrm{C}$. By contrast, the lowest average $\mathrm{NH}_{3}-\mathrm{N}$ and TN removal rates were $64.7 \%$ and $55.4 \%$, respectively, at an underground temperature of $12 \pm 1.3^{\circ} \mathrm{C}$. Average $\mathrm{NH}_{3}-\mathrm{N}$ removal rate significantly increased from $64.7 \%$ at underground temperature of $12 \pm 1.3^{\circ} \mathrm{C}$ to $82.1 \%$ at $16 \pm 1.6^{\circ} \mathrm{C}$. Temperature had positive effects on $\mathrm{NH}_{3}-\mathrm{N}$ and TN removal. $\mathrm{NH}_{3}-\mathrm{N}$ and TN removal rates increased with increasing underground temperature. Normally, the biotic reaction depended on temperature and therefore was strongly seasonal. In a SWIS, nitrification coupled with denitrification is the major removal process for nitrogen. Nitrification is a limiting step for nitrogen removal in a SWIS (Pan et al., 2013). To maintain the biological activity of nitrifying bacteria, temperature was an important factor. Based on previous studies, the difference in nitrogen removal was fairly large between the warm and cold periods (> 10\%), and nitrification was more sensitive to temperature in colder environments (temperatures $<15^{\circ} \mathrm{C}$ ) (Zhang et al., 2008). In this study, the in-situ temperature monitor showed that the temperature $0.5 \mathrm{~m}$ below ground remained below 12 $\pm 1.3^{\circ} \mathrm{C}$ in January. Therefore, nitrification and denitrification processes were not good relative to warm periods. The effluent concentrations for COD, TP, $\mathrm{NH}_{3}-\mathrm{N}$ and TN were $48.2 \pm 1.1,0.36$ $\pm 0.01,13.1 \pm 0.5,18.6 \pm 0.6 \mathrm{mg} / \mathrm{L}$, respectively, with an average outdoor temperature of $-19^{\circ} \mathrm{C}$ during the study period, which were lower than Chinese criterion for Water Quality Standard for Urban Miscellaneous Water Consumption (CJ 25.1-89 1). The effluent could be used for cleaning, flushing toilets and irrigating the landscape. The SWIS needed a larger land area because of the relatively low hydraulic loading rate $\left(0.10 \mathrm{~m}^{3} /\left(\mathrm{m}^{2} \cdot \mathrm{d}\right)\right.$ reported herein). Therefore, the SWIS technology is more applicable for a small community, suburban and rural areas having on-site domestic wastewater treatment and reuse, and which have access to a large land area.

As seen from Fig. 9, when underground temperature increased by about $4^{\circ} \mathrm{C}$, the number of bacteria in each layer increased 10 times. The number of nitrification and denitrification bacteria varied with temperature (Zhang et al., 2008). When underground temperature increased by about $4^{\circ} \mathrm{C}$, the number of nitrifying bacteria increased 10 times at 0.4 and $0.6 \mathrm{~m}$ depths and the number of denitrifying bacteria increased 10 times at 0.8 and 1.0 $\mathrm{m}$ depths. At underground temperature of $12 \pm 1.3^{\circ} \mathrm{C}$, the number of nitrification and denitrification bacteria was lowest. This could further explain the lowest nitrogen removal rate which occurred at this low underground temperature.

\section{CONCLUSIONS}

$\mathrm{NH}_{3}-\mathrm{N}, \mathrm{TN}$ and COD removal rates decreased with increasing HLR or OLR, and increased with increasing underground temperature. The number of nitrifying bacteria decreased with increasing HLR and OLR, and increased with increasing underground temperature at 0.4 and $0.6 \mathrm{~m}$ depths. The number of denitrifying bacteria increased with increasing HLR, OLR and underground temperature, at 0.8 and $1.0 \mathrm{~m}$ depths. Taking the hydraulic and treatment performance into consideration, HLR of $0.10 \mathrm{~m}^{3} /\left(\mathrm{m}^{2} \cdot \mathrm{d}\right)$ was recommended with average $\mathrm{NH}_{3}-\mathrm{N}$, TN, COD and TP removal rates of $82.6 \%, 81.5 \%, 80.9 \%$ and $90.9 \%$, respectively. Considering treatment performance, OLR of $10.4 \mathrm{~g} \mathrm{BOD} /\left(\mathrm{m}^{2} \cdot \mathrm{d}\right)$ was recommended with average $\mathrm{NH}_{3}-\mathrm{N}$, $\mathrm{TN}, \mathrm{COD}$ and TP removal rates of $88.1 \%, 84.8 \%, 86.3 \%$ and $91.3 \%$, respectively. Due to the relatively low HLR, the SWIS needs a large land area. Therefore, it is fit for small community
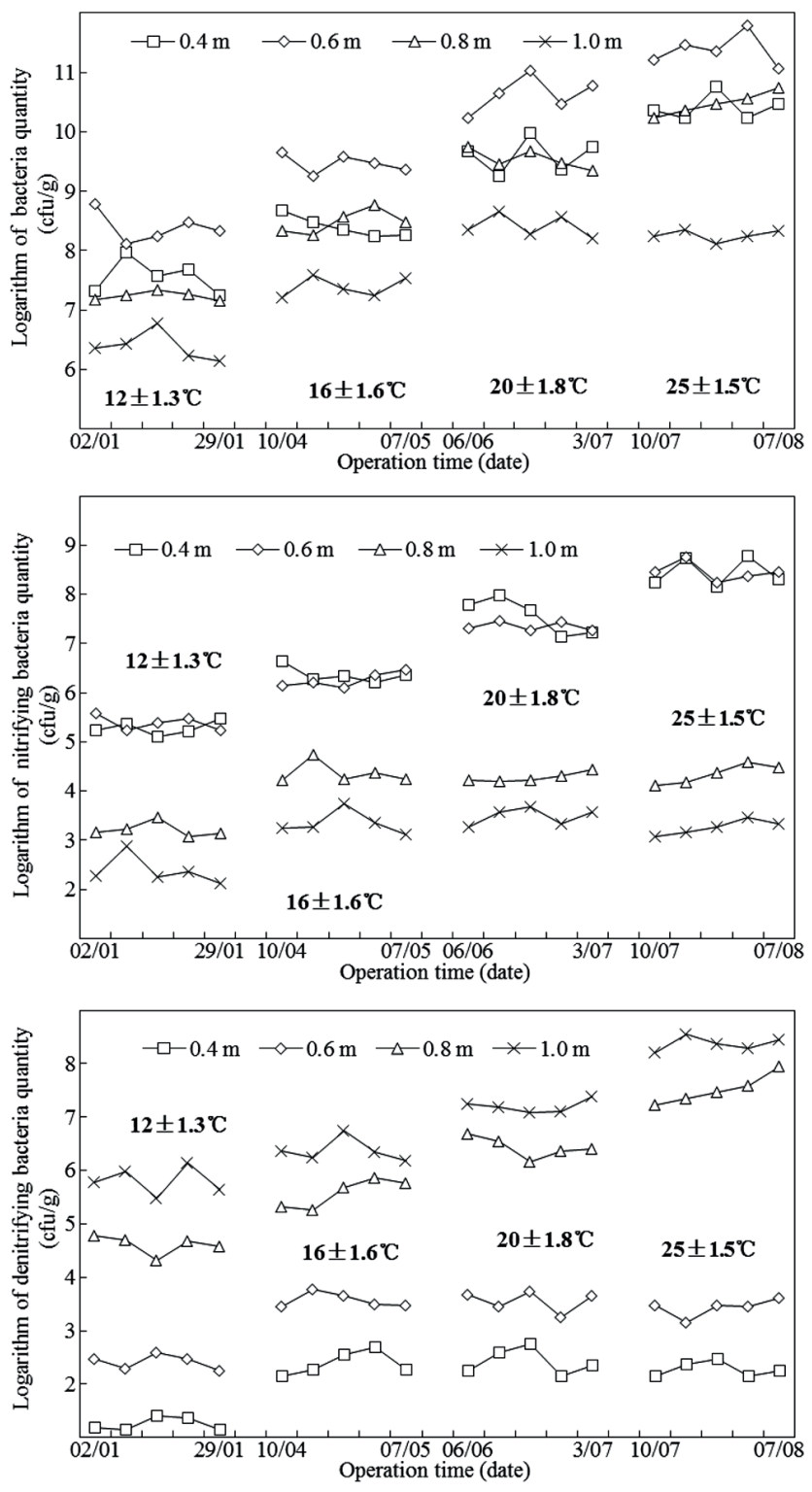

Figure 9

Effect of underground temperature on microbial community

on-site wastewater treatment, such as campus and rural areas, which could fulfil the land requirement. The application of SWISs in other regions requires further investigation, as does the potential for application of enhancing technologies.

\section{ACKNOWLEDGEMENTS}

This research was financially supported by the National Natural Science Foundation of China (No.41471394, 41601314, 41001321); Liaoning BaiQianWan Talents Program [2015(45)]; Natural Science Foundation of Liaoning; Shenyang Science and Technology Project [18-013-0-43].

\section{REFERENCES}

AMERICAN PUBLIC HEALTH ASSOCIATION (APHA) (2003) Standard Methods for the Examination of Water and Wastewater. American Public Health Association/American Water Works Association/Water Environment Federation, Washington, DC. 
BROOKS AS, ROZENWALD MN, GEOHRING LD, LION LW and STEENHUIS TS (2000) Phosphorus removal by wollastonite: a constructed wetland substrate. Ecol. Eng. 15, 121-132. https://doi. org/10.1016/S0925-8574(99)00056-7

FEI HX, TONG DL, PAN J, ZHANG Y, HUANG LL, CHENG F and ZHENG FP (2016) Pollutant removal in subsurface wastewater infiltration systems with/without intermittent aeration under different organic pollutant loadings Water SA 42 595-600. https:// doi.org/10.4314/wsa.v42i4.09

KADAM AM, NEMADE PD, OZA GH and SHANKAR HS (2009) Treatment of municipal wastewater using laterite-based constructed soil filter. Ecol. Eng. 35 1051-1061. https://doi. org/10.1016/j.ecoleng.2009.03.008

LI HB, LI YH, SUN TH and WANG X (2012) The use of a subsurface infiltration system in treating campus sewage under variable loading rates. Ecol. Eng. 38 105-109. https://doi.org/10.1016/j. ecoleng.2011.10.012

LI YH, LI HB, SUN TH and WANG X (2011a) Study on nitrogen removal enhanced by shunt distributing wastewater in a constructed subsurface infiltration system under intermittent operation mode. J. Hazardous Mater. 189 336-341. https://doi. org/10.1016/j.jhazmat.2011.02.039

LI YH, LI HB, SUN TH and WANG X (2011b) Effects of hydraulic loading rate on pollutants removal by a deep subsurface wastewater infiltration system. Ecol. Eng. 37 1425-1429. https://doi. org/10.1016/j.ecoleng.2011.03.029

MOLLE P, LIÉNARD A, GRASMICK A and IWEMA A (2006) Effect of reeds and feeding operations on hydraulic behavior of vertical flow constructed wetlands under hydraulic overloads. Water Res. 40 606-612. https://doi.org/10.1016/j.watres.2005.11.026

PAN J, YU L, LI GZ and HUANG LL (2013) Characteristics of microbial populations and enzyme activities in non-shunt and shunt subsurface wastewater infiltration systems during nitrogen removal. Ecol. Eng. 61 127-132. https://doi.org/10.1016/j. ecoleng.2013.09.025

RAUCH WT and DREWES JE (2006) Using soil biomass as an indicator for the biological removal of effluent-derived organic carbon during soil infiltration. Water Res. 40 961-968. https://doi. org/10.1016/j.watres.2006.01.007

SATO K, MASUNAGA T and WAKATSUKI T (2005) Characterization of treatment processes and mechanisms of COD, phosphorus and nitrogen removal in a multi-soil-layering system. Soil. Sci. Plant Nutr. 51 213-221. https://doi.org/10.1111/j.1747-0765.2005. tb00025.x

WANG X, SUN TH, LI HB, LI YH and PAN J (2010) Nitrogen removal enhanced by shunt distributing wastewater in a subsurface wastewater infiltration system. Ecol. Eng. 36 1433-1438. https://doi. org/10.1016/j.ecoleng.2010.06.023

YIN H and SHEN W (1995) Using reed beds for winter operation of wetland treatment system for wastewater. Water Sci. Technol. 32 111-117. https://doi.org/10.2166/wst.1995.0132

ZHANG J, HUANG X, LIU CX, SHI HC and HU HY (2005) Nitrogen removal enhanced by intermittent operation in a subsurface wastewater infiltration system. Ecol. Eng. 25 419-428. https://doi. org/10.1016/j.ecoleng.2005.06.011

ZHANG YL, DAI JL, WANG RQ and ZHANG J (2008) Effects of longterm sewage irrigation on agricultural soil microbial structural and functional characterizations in Shandong, China. Eur. J. Soil Biochem. 44 84-91. https://doi.org/10.1016/j.ejsobi.2007.10.003

ZOU JL, DAI Y, SUN TH, LI YH, LI GB and LI QY (2009) Effect of amended soil and hydraulic load on enhanced biological nitrogen removal in lab-scale SWIS. J. Hazardous Mater. 163 816-822. https://doi.org/10.1016/j.jhazmat.2008.07.030 